\title{
BOOKS ON THE BORDER WAR, 1966-1990
}

\author{
Col (Dr) C.J Jacobs \\ Senior Researcher and Military Historian \\ South African National War College.
}

- $\quad$ De Vries, R. 2013. In the eye of the firestorm; Paarl: Naledi.

- Scholtz, L. 2013. The SADF in the Border War, 1966-1989. Cape Town: Tafelberg.

- Bothma, LJ. 2012. Vang 'n Boer. Bloemfontein: Self publication.

On 11 December 2008, at the monthly meeting of the South African Military History Association in Saxonwald, Johannesburg, Dawid Williams introduced his book On the Border, 1965-1990. ${ }^{1} \mathrm{He}$ remarked that the shooting war in Namibia was over, but that the war of words had only just begun. The arguments as to who occupied the moral high ground and who emerged victorious continue unabated in the tradition of the Dutch historian Pieter Geyl's remark that history is a debate without end. ${ }^{2}$

On completion of the war, Willem Steenkamp ${ }^{3}$ published a large-format coffee table book and shortly afterwards, FJ du Toit Spies wrote a book on operation Savannah, 1975-1976. ${ }^{4}$ Ashanti also published Fred Bridgeland's The war for Africa and Helmoed-Römer Heitman, War in Angola - The final South African phase. ${ }^{5}$ These books interpreted history from the perspective of the South African Defence Force (SADF) and were probably intended to boost the image of the war organisation and its members in the aftermath of the war.

After 1994, a multitude of publications claimed that the South African Defence Force had been defeated near the town of Cuito Cuanavale, leading to the independence of Namibia in 1989, and sweeping political changes in South Africa itself. This is the main line of the arguments in the autobiography of Cuba's Fidel Castro, My life. ${ }^{6}$ Complementary to this, An unpopular war ${ }^{7}$ left the impression that a large number of conscripts of the SADF only served in order to escape

Scientia Militaria, South African Journal of Military Studies, Vol

41, Nr 2, 2013, pp. 1-33

doi : $10.5787 / 41-2-1072$ imprisonment for refusing to respond to the call up for duty.

The central question is to which extent the three books under discussion contribute to 
the bringing us closer to the truth as to what happened and the meaning of the war that lasted from 1966 to 1989 . Louis Bothma, author of Vang $n$ Boer, ${ }^{8}$ is a selftaught historian who is actually an agricultural economist, who served as a junior officer in 32 Battalion, the SADF's foreign legion of Angolans who served with the Portuguese until 1975 and developed into a crack elite unit. The second book is written by Leopold Scholtz, a well-known military historian, employed as Media 24's representative in Europe, under the title The SADF in the Border War, 1966$1989,{ }^{9}$ while the third was written by Roland de Vries, ${ }^{10}$ a retired major general from the SANDF. The title is In the eye of the firestorm.

Bothma's book unfortunately does not address the period after 1978 as a follow-up publication will focus on the period after that date until 1989. He traces the origins of the conflict in Namibia back to the turbulent pre-colonial past when different ethnic groups settled in the country. Genocide and war were common until the Germans restored law and order in 1884. However, the Germans also triggered new wars with their policies in the territory. Central to these events were the different Ovambo tribes who lived astride the Angolan/Namibian border and resisted Portuguese and German colonial rule respectively. They would later also form the core of the resistance against South African rule until 1989.

Central to the discussion is that Bothma sees the conflict as between two peoples brought together by fate when the South African government decided in 1914 to invade the German colony on request of the British. Some Boer generals, such as the famous guerrilla leader, Christiaan de Wet, and Christian Beyers, the then serving commandant-general of the Citizen Forces of the Union Defence Force rebelled against this as they regarded it as an immoral act against a nation (Germany) who had done the Afrikaners no harm for the sake of a former enemy who subjugated the Boer republics in a manner that left a legacy of bitterness. The 1914 Rebellion was however quickly suppressed, and after the occupation of German South West Africa by the Union Defence Force in 1915, the Afrikaners found themselves as colonial masters in a neighbouring country. In 1917, the first Afrikaner soldiers died in a war against the Ovambo people when the latter rebelled against the new colonial overlord. Bothma describes the rise of two ethnic nationalisms, that of the Afrikaners in South Africa and the eventual rise of the South West Africa People's Organisation (SWAPO) in Namibia that would clash in 1960 and lead to a war that lasted until 1989. The author focuses on the irony of the descendants of the Afrikaner nationalists who rebelled against the invasion of Namibia in 1914. These Afrikaner descendants would for more than 20 years conduct a war. At first, they tried to prevent the independence of Namibia and later accepted this inevitability, but on their own terms. 
The book is well written and hopefully the English translators will do justice to the deft using of Afrikaans that provides a blow-by-blow account until 1978 when events led to an even sharper escalation of the conflict. This is not a work on strategy and tactics, but a partial personal experience showing deep empathy with the ordinary fighting men on both sides, their motivations, frustrations and eventual partial disillusionment with a war that somehow did not always make sense. Elaborate research in archives and interviews with members of SWAPO's military wing, the People's Liberation Army of Namibia (PLAN) provides credibility as the events are analysed from both perspectives. The author pulls no punches and elaborately weaves the atrocities committed by both sides into the pattern of events. The story culminates in a specific event when fate brought together two men: Danger Ashipala, an Ovambo and PLAN combat officer, and an Afrikaner sapper, Johan van der Mescht, as symbols of the clash of wills of two peoples in this war. Van der Mescht's capture by Ashipala, his eventual release and their meeting again many years after the event somehow describes the senselessness of war and the reasons why people conducted it.

Unfortunately historical writing is not just about ordinary people being dragged along by conflicting ideologies. The historian's task is also to try and comprehend the decisions and actions of politicians and military leaders within the context of the times during which they lived. One gets the impression that the author tries to belittle the South African government's perception of the danger involvement by the Soviet Union and Cuba posed for all the inhabitants of Southern Africa. Whether the perceptions of the time were a true reflection of the motives of the Soviet and Cuban leadership needs to be confirmed by historical research, but there was an unmistaken pattern of using military power to install regimes that allowed no opposition or any personal freedom bar adherence to Marxist dogma. From Eastern Europe in 1945, China in 1949 and since 1975 in Ethiopia, Mozambique and Angola, it seemed as if nothing would stop Marxism to prevail globally. The Soviet invasion of Afghanistan strengthened this trend. Just as Danger Ashipala was probably not an ardent Marxist, the same can be said of the rank and file of South African officers and soldiers in terms of apartheid and separate development.

Another aspect that the author ignores is that since 1917, certain interests for Afrikaners were established in Namibia. He mentions the fact that several Afrikaners settled there as farmers and businessmen in the period after 1919 when the territory became a Class C Mandate under South African rule under the old League of Nations. These people contributed to the National Party election victory in 1948 and the yes vote for a republic in 1960. Thus, the perception was created 
that they could not simply be written off. However, an even more important fact, that Bothma ignores, is that Namibia acted as a buffer against insurgency in South Africa itself in the period 1960-1965. Thus, the South African government was confronted with the horns of a dilemma as it would be difficult to conduct a war along long lines of communication and with the largest ethnic group, the Ovambo, supporting SWAPO. Yet, the perception was that this was easier than to absorb the psychological impact of surrendering the territory to an insurgent group and allowing them to infiltrate across the Orange River. This was well analysed by Toase $^{11}$ in 1985 .

Scholtz's book approaches the ideological issues in a balanced manner when he describes the role of different political ideologies as if in an overlay, each exerting influences in the decisions taken by the respective sides in the conflict. Since 1945, the South African government found itself in the same position as that of other European colonial powers. First there was a reluctance to let go of power, and then a drawn-out counterinsurgency war in which the wise decision was to declare the willingness to grant independence and fight alongside moderate indigenous forces to prevent radical ideologues from grabbing power and subjugating the people to a worse fate than colonialism. ${ }^{12}$ The dilemma for the South African government was that by 1966 , the United Nations was so dominated by the Afro-Asiatic block that nothing but the handing over of power to SWAPO would have sufficed.

Scholtz starts off with the immediate causes of the war, and then focuses on campaign strategy and the evolution of military thinking in the SADF in an effort to find answers to an escalating insurgency, protected by the conventional forces of Angola and Cuba. He states that his book is but a first report about the war and that more detailed research is needed. Taking into account the extensive research in the SANDF archives and use of Cuban and Soviet archives and interviews with participants, further researchers face the huge task of beating this book in terms of a broad, yet detailed enough description of the major operations into Angola and the counterinsurgency campaign in Namibia itself. Scholtz is critical of previous SADF generals who claimed that they had won the war, and then describes the last phase of the war as one leading to a stalemate from which all the belligerents wanted to withdraw. He comes to the conclusion that the SADF actually gained more than it bargained for in that UN Resolution 435 could be implemented with an agreement that the Cubans had to leave Angola and Umkhonto we Sizwe (MK), the military wing of the African National Congress, which had to move their training bases to Uganda and Tanzania. Still, he admits, at operational level, the SADF was 
temporarily outmanoeuvred by being fixed at Cuito Cuanavale and the Cuban elite $50^{\text {th }}$ Division deployed north of Calueque, poised to invade Namibia.

In 1986, John Keegan and Andrew Wheatcroft ${ }^{13}$ described South Africa's defence problems as wars on too many fronts. They talk about a draining conflict in Namibia, battles to preserve an economy under siege through sanctions and the escalation of violent uprisings in South Africa itself. They elaborated on the long lines of communication to fight a war in northern Namibia and Southern Angola and claimed that withdrawal from Namibia would enable the government to combat the insurgency in South Africa itself more effectively. This level of interaction with the national strategic level is the one aspect not addressed by the author and, taken into account his vast knowledge and experience in this regard, the only disappointment of the book. An aspect of this is the impact of the war on the South African economy. According to SADF-provided figures, the war cost the South African taxpayer more or less R2 million per day. ${ }^{14}$ Surely this could have been used far more effectively in an all-encompassing counterinsurgency war in South Africa itself?

In fairness it must be stated that the author to a large extent did address these issues in two articles in Scientia Militaria, namely, The Namibian Border War: An Appraisal of the South African Strategy, Vol. 34, No. 1, 2006 and The South African Strategic and Operational Objectives in Angola, 1987-88, Vol. 38, No. 1, 2010. It is unfortunate that he apparently decided to allocate only a small portion in the book to this.

De Vries gained fame as a war philosopher in 1987 when he published his book Mobiele oorlogvoering - ' $\mathrm{P}$ Perspektief vir Suider-Afrika. ${ }^{15} \mathrm{He}$ was also one of the pioneers who developed the concept of mechanised infantry in the South African Army and specifically the Ratel infantry combat vehicle. He is well known as a leader of men, and with his outspokenness made some enemies, but mostly gained admirers as the majority of officers in the Army realised that his ideas presented the only alternative in a war in which the SADF had to fight against numerically stronger enemies, over difficult terrain, long lines of communication and having to curb an insurgency where the Ovambo tribes straddling the border were the main source of support for SWAPO.

His ideas were again incorporated into In the eye of the firestorm and he extensively describes how these ideas were implemented and eventually ignored. $\mathrm{He}$ was privileged to serve in the most important cross-border operations, being appointed by the Chief of the Army to plan the possibility to attack Cuito Cuanavale 
from the west and as Chief of Staff to Deon Ferreira, the officer commanding $8^{\text {th }}$ Brigade, when the decision was taken to conduct operations only east of the Cuito River. He also describes his appointment as the Chief of Staff of 10 SA Division that deployed south of Ruacana to counter the Cuban $50^{\text {th }}$ Division and prevent this formation from invading Namibia. Reading his exploits, one realises that the SADF was temporarily outmanoeuvred at Cuito Cuanavale, but with the deployment of 10 Division, partially regained the initiative.

This is not just a book about the exploits of a good leader and a clear thinker of war. His personal experiences and his leadership style make for good reading for junior and senior officers in any defence establishment. He also destroys the myth about the large number of conscripts who only served by coercion by describing his interaction with his men and the enthusiasm with which the South Africans served their country. His enthusiasm is further displayed in his role in the transformation process and the creation of the South African National Defence Force.

To balance his views one should however point out that attrition and positional warfare are not always the same. To cite an example from his book, he describes the battle of Majuba as a masterful execution of tactical manoeuvre warfare, but the truth lies deeper. If Joubert's Boer force did not occupy Laings Nek and defended it to the hilt, Colley would simply have advanced into the Transvaal and relieved the besieged British garrisons. ${ }^{16}$ Another example is the defence of the British $8^{\text {th }}$ Army at El Alamein in July 1942. This prevented Rommel's Panzerarmee Afrika from capturing the Suez Canal and the Persian Gulf oilfields, without which the British Empire would not have been able to participate further in the war. ${ }^{17}$ At the operational level of war, the defence of a key region at all costs might have been the key to the achievement of results at strategic level. Schneider, ${ }^{18}$ characterised Operational Art (campaign strategy after Napoleon) as consisting of two components, namely a distributed free manoeuvre in a theatre and the defence of critical resource-laden territories. Thus, occupation of key regions and their defence constitute a form of manoeuvre at operational level. After all, was it not the task of the $10^{\text {th }}$ Division to destroy the Cuban $50^{\text {th }}$ Division if they attempted to invade Namibia? De Vries describes in detail the plan for mobile defence against such a possibility, but still had to fight to keep control of a critical important territory.

One should also point out that manoeuvre warfare does not always provide a wonder solution. Germany lost both world wars in the $20^{\text {th }}$ century, in spite of being far more proficient in manoeuvre warfare than her adversaries. Tuck ${ }^{19}$ emphasises that in the long run, all warfare degenerates into a process of attrition and warns against the idea that there is only one conventional doctrine that can guarantee 
victory. According to him, military effectiveness lies with intangibles, such as the capacity to adapt relative to the opponent.

Both Scholtz and De Vries mention PLAN's invasion of Namibia after UNTAG had already been deployed and the SADF was confined to their bases. Much is said about the immorality of this action and the way it progressed. The central question is however, which effect did this have on the Ovambo tribes, the key to who would win the first democratic election in Namibia? Could such an election really be called free and fair and was it really a victory for democracy as both authors claim?

All three books are well researched and well written. They contribute substantially to the further discovery of the truth of the sequence of events of the war and its meaning in Southern Africa. I would recommend all SANDF libraries to purchase the books (Bothma's English version albeit) and that students in the Joint Senior and Command Programme and on Junior Staff Courses be encouraged to read it.

\section{Endnotes}

${ }^{1}$ Williams, D. Op die grens: Wit mans se militêre ervaring. Cape Town: Tafelberg, 2008.

${ }^{2}$ Spies, S.B. The Historian's Net, Inaugural Lecture, University of South Africa, Pretoria, 1981, 1.

${ }^{3}$ Steenkamp, W. South Africa's Border War. Gibraltar: Ashanti, 1989.

${ }^{4}$ Spies, FJ du Toit. Angola: Operasie Savannah, 1975-76. Pretoria: Defence Force, 1989.

${ }^{5}$ Both published by Ashanti, 1989.

${ }^{6}$ Castro, F. My life. New York: Scriber Books, 2006.

${ }^{7}$ Thompson, JH. An unpopular war. Cape Town: Zebra Press, 2006.

${ }^{8}$ Bothma, LJ. Vang 'n Boer. Bloemfontein: Author, 2012.

${ }^{9}$ Scholtz, L. Die SAW in die Grensoorlog, 1966-1989. Cape Town: Tafelberg, 2013.

${ }^{10} \mathrm{De}$ Vries, R. In the eye of the firestorm. Paarl: Naledi, 2013.

${ }^{11}$ Toase, F. "The South African Army: The campaign in South West Africa/Namibia since 1966". In Beckett, IFW \& Pimlott, J (eds), Armed forces \& modern counter-insurgency, London: Croom Helm, 1985, 190-219.

${ }^{12}$ See in this regard Mockaitis, TR. British counterinsurgency, 1919-1960. London: Macmillan, 1988 .

${ }^{13}$ Keegan, J \& Wheatcroft, A. The World Strategic Atlas. London: Jonathan Cape, 1986, 69-73 .

${ }^{14}$ Barnard, SL. "'n Historiese oorsig van die gewapende konflik aan die noordgrens van SWA/Namibië, 1966-1989”. Acta Academica 23/1. 1991. 103. 
${ }^{15}$ De Vries, R. Mobiele oorlogvoering: 'n Perspektief vir Suider-Afrika. Silverton: Harman, 1987.

${ }^{16}$ Van Jaarsveld, FA, Van Rensburg, APJ \& Stals, WA (eds). Die Eerste Vryheidsoorlog, 1880-1881. Pretoria: HAUM, 1980.

${ }^{17}$ Jacobs, CJ. "' n Evaluering van die rol van die 1ste Suid-Afrikaanse Infanteriedivisie tydens die Eerste Slag van El Alamein, 1-30 Julie 1942." Unpublished MA thesis. University of Stellenbosch, 1989, 250.

${ }^{18}$ Schneider, JJ. "Theoretical implications of operational art". In Newell, CR \& Krause, MD (eds), On operational art, Washington, DC: US Army Center for Military History, 1994, 18.

${ }^{19}$ Tuck, C. "Land warfare”. In Jordan, D \& Kiras, JD ,Lonsdale,D.J., Speller,I. Tuck, C. \& Walton, D. Understanding modern warfare, Cambridge: Cambridge University Press, 2011, 115. 